\title{
The Complexities of Lobbying: Toward a Deeper Understanding of the Profession
}

\author{
Lee Drutman, University of California, Berkeley, 2009-1o APSA Congressional Fellow
}

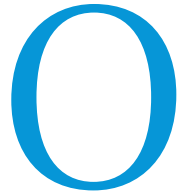

ne of the ongoing challenges for interest group scholars has been to explain exactly how lobbying works. What is it that lobbyists actually do? What are their sources of influence? While a few landmark surveys of lobbying activity (Scholzman and Tierney 1986; Heinz et al. 1993) have shown lobbying to be a remarkably variegated phenomenon-with lobbyists employing a wide range of tactics and strategies, all with less than predictable rates of success-the literature on interest groups has tended toward a parsimonious theory of lobbying. Numerous scholars have attempted to distill lobbying to primarily one concept: for example, a transactional marketplace where votes are traded for electoral support, a process of working with allies, or an information transmission process. This article argues that it is not so easy to boil lobbying down to just one thing.

The analysis presented here is based on my personal experience as a 2009-10 APSA Congressional Fellow. In December 2009, I joined the banking and housing team of a Democratic Senate office. The dominant issue during my time on the team was financial regulation reform-what would eventually become the Dodd-Frank bill. When I first arrived, Senator Christopher Dodd (D-CT), the then-chairman of the Committee on Banking, Housing, and Urban Affairs, had recently issued his discussion draft. Within a week of my arrival, the House had passed its version of the bill (H.R. 4173), and all attention shifted to the Senate, with a date uncertain for passage.

When I arrived, the office's legislative counsel for banking and housing issues (my supervisor) was sorting his way through roughly 30 proposed amendments to Dodd's discussion draft. The senator for whom I worked, I was told, was interested in playing an active role in the committee and wanted to make sure his priorities were included in the bill. Therefore, the bulk of my job initially was to follow the Senator's lead in preparing his amendments-to vet them with outside experts and regulatory agencies that would be affected and, ultimately, draft them for future review with the Senator again (often with the help of legislative counsel). The pre-mark-up period lasted until March 22, when a new version of the bill-S. 3217-passed by a 13-10 vote (strictly partisan) in a remarkable 20 minutes. No senators offered amendments, which came as a surprise to many of us working on the bill, who had expected a contentious partisan mark-up, given the more than 500 amendments that had been filed. However, the banking committee staff, who played a central role in the process, had already agreed to add many noncontroversial amendments, including many of ours, to the text of S. 3217 between December and March.

The full Senate agreed to open debate on the legislation on April 28, and the bill stayed on the floor for three weeks, during which time the chamber voted on exactly 50 amendments and senators filed 435. There were many behind-the-scenes negotiations about who would be allowed to offer amendments, and many senators on the floor grew increasingly frustrated as it became clear that either Chairman Dodd was not going to let their amendments come up for a vote, or that a Republican was going to refuse to agree to a unanimous consent agreement. I was responsible for writing vote recommendations on amendments, providing pro and con arguments to the senator for whom I worked as best I could, sometimes in a very short time. On May 19, the Senate passed the bill with 60 votes, including four cast by Republicans. The bill then spent several weeks in a House-Senate conference and finally came back to the Senate floor for a final vote on July 15, passing 60-39 (though this time with only three Republicans).

My responsibilities also included handling meeting requests from constituents, interest groups, and lobbyists, and during my time in the office, I logged 89 such meetings related to the Wall Street reform bill. I was instructed to primarily listen-to let any group that wanted to register a concern know that I would pass that concern along to the Senator, and that he would take their concerns under consideration if and when he had to vote on a particular amendment that was relevant to the group. Groups frequently wanted information-when did I think the mark-up was going to be done, or when was the bill going to the floor? And, of course, what was the Senator's position on issue X? When appropriate, I let groups know where the Senator stood on an issue. At the end of each meeting, I was responsible for preparing a quick summary of what had occurred, which I included in the weekly report I submitted to the Senator. I also often discussed the meetings with my supervisor.

Lobbying activity was heaviest in the leadup to the committee mark-up. In the weeks between my arrival and the bill mark-up, I averaged 4.7 meetings per week. After the mark-up, my meeting requests declined by almost 50\%, down to 2.6 per week (see table 1). Of course, once the bill was on the floor, I received much more e-mail traffic, which increased to a blizzard as amendments came up for a vote. Given the patterns I observed, meetings were presumably most valuable to outside groups when there was still a chance to shape the contours of the bill.

\section{THEORIES OF LOBBYING AND THEIR} APPLICABILITY

The literature on lobbying offers three main theories of what lobbying is primarily about: (1) It is a quid pro quo exchange process; (2) it is about working with allies; and (3) it is about providing expert information and using that information to persuade. I will proceed by discussing each of these theories briefly and then evaluating them based on my experiences.

\section{Lobbying Is an Exchange Process}

One way of thinking views interest group influence as an exchange process in which members of Congress agree to support legislation and advocate for certain special interests in exchange for electoral support from those special interests, primarily in the form of campaign contributions. According to this outlook, "Campaign fundraising is 
Table 1.

\section{Meetings, by Stage of Process}

\begin{tabular}{lccc} 
STAGE & MEETINGS (N) & WEEKS & MEETINGS/WEEK \\
\hline Pre-Committee Mark-Up & 66 & 14 & 4.7 \\
Between Committee and Floor & 13 & 5 & 2.6 \\
On Floor & 10 & 4 & 2.5
\end{tabular}

Many groups also came to us hoping that the Senator would be an ally. More than a third of the meetings I held (33, or $37 \%)$ concerned requests by groups to add something to the legislation.

widely viewed as a market for public policy. Donations come from firms, associations, and individuals that seek private benefits in the form of subsidies, favorable regulations, and other policies set by the government. With thousands of interests bidding for private benefits and thousands of candidates vying for funds, something like a market emerges" (Ansolabehere, de Figueiredo, and Snyder 2003, 109).

I encountered no first-hand evidence to support this theory. There was not a single meeting that I held in which I was told ahead of time or afterwards that this particular group was an important campaign contributor. Rather, I was instructed to schedule meetings with anyone who requested a meeting, consistent with the office policy of broad accessibility. Neither in formulating the Senator's positions nor in producing vote recommendations for amendments was I ever directly instructed to consider (or even made aware of) who supported the Senator electorally.

The content of all my meetings was substantive policy discussion. Lobbyists expended substantial effort to convince me of the merits of their position. (Lobbyists tend to view staffers as conduits to senators.) They presented detailed arguments, often accompanied by research; made numerous appeals to fairness (just about everybody made some version of the argument: "We didn't cause the crisis. Why are we being targeted?"); and offered many dire warnings about the "unintended consequences" that particular provisions would have on jobs and the economy. But never did a lobbyist bring up (even in a wink-wink, nudge-nudge manner) the issue of electoral support.

\section{Lobbying Is Primarily about Work- ing with Allies}

A second way of thinking views interest group influence as primarily a process of working with allies-that is, with those who are already favorably disposed to a particular position. Hall and Deardorff (2006) have most coherently called this view "lobbying as legislative subsidy." Building on a large body of literature that finds consistent support for interest groups that work primarily with their allies (Bauer, Pool, and Dexter 1972; Milbrath 1963; Kollman 1997; Hojnacki and Kimball 1998), Hall and Deardorff make the case that "the proximate objective of this strategy is not to change legislators' minds but to assist natural allies in achieving their own, coincident objectives" (2006, 69). Since developing and enacting policy is a time-consuming affair and legislative staff throughout Congress are stretched incredibly thin, the staff understandably tend to lack the deep expertise that corporate and non-profit representatives have in a specific policy area. Interest groups, meanwhile, know that the key to success is identifying and then fortifying potential "champions." This approach implies that interest groups focus primarily on like-minded legislators who have the actual power to introduce legislation.

I found substantial support for this hypothesis in my daily dealings. Particularly when the Senator had picked certain issues on which he wished to lead, the best way that we as staffers could effectively advance these issues was to work with outside groups. We sought their advice on specific policy details and help in building support for the particular policy in the press and with other offices. During this period, we were in frequent contact with these groups.

However, of the 89 meeting requests to which I agreed, only 11 (12\%) were with groups that I would consider allies. (I define allies as groups with which the Senator was clearly in agreement on many issues.) This low percentage may be because the Senator was already aligned with many non-profit advocacy groups, or because there are many more groups representing corporations and trade associations generally. Or these groups may not have felt the need to formally schedule meetings, perceiving the channels of communication to be already open. Indeed, I conducted many, many phone and e-mail conversations with allies-generally consumer advocates.
These groups generally saw the Wall Street reform bill as an opportunity for the inclusion of some proposal they favored. What they were doing was shopping for a "champion" who would introduce their amendment and then fight for it. However, the Senator was much more interested in amendments that would benefit the general public rather than a narrow constituency.

\section{Lobbying Is Primarily about Infor- mation Provision and Persuasion}

A third view is that lobbying is primarily about persuasion by information transmission. Hansen (1991) describes lobbying as primarily engaged in providing information about constituency views, with groups pressing lawmakers to enact particular policies based on how constituents will respond. Wright offers a similar view, arguing that interest groups "achieve influence through the acquisition of and strategic transmission of information that legislators need to make good public policy and get reelected" (1996, 2). Esterling (2004) describes interest groups as vital to the process of enacting good public policy by their provision of expert information, and he shows that demonstrated technical expertise actually improves access. Austen-Smith and Wright (1994) conceive of lobbying as primarily about rebutting claims made by opponents. What all these approaches have in common is that they frame lobbying as a process that is primarily concerned with changing opinions. They either explicitly or implicitly suggest that lobbying allies is a waste of time and predict that lobbying efforts by allies are limited.

This theory resonated with a significant amount of lobbying activity I observed. As described previously, most of my meetings involved substantive policy discussions in which lobbyists hoped that by presenting their case in a reasoned way, they could ultimately convince the Senator that their position was good public policy.

The vast majority of meetings I held (62) were with what I would call "neutrals"neither enemies nor allies-or groups who 
wanted to communicate their views to the Senator in hopes of getting him to support their position, usually without knowing where he stood on an issue. These groups did not tend to have previous relations to the staff or the Senator. Part of these meetings clearly involved persuasion. These groups wanted to make sure that I understood the issue and, in particular, why whatever the bill was currently doing would have "unintended consequences" that would impact the group's constituency negatively upon passage, such as killing jobs or driving them overseas, making consumers pay more, or reducing competition. There was a remarkable consistency in the way that these stock arguments were trotted out. These groups were also frequently interested in trying to gauge the state of play, glean insight about what was going to happen and when, and establish what was happening with various members. (This constant quest for information confirms the findings of both Heinz et al [1993] and Schlozman and Tierney [1986], who find a sizeable monitoring component to lobbying-lobbyists want to know where different offices stand on different issues, when different bills are likely to move, and so on.)

Most of these meetings with neutrals (40, or $65 \%$ ) involved requests to change an existing provision. An additional 22 meetings (34\%) involved requests to add something to the legislation (discussed previously). Finally, 10 of the 62 meetings ( $15 \%$ ) involved a request to keep the bill the way it was. These meetings assumed that there would be future attempts to alter the legislation, and the groups wanted to make sure that our office understood the reasons why the particular provision was important to keep.

I also held 15 meetings with groups who were unhappy with the Senator's public position and hoped he would change his mind or reconsider. Such meetings were, in my estimation, ineffective. I felt as though the groups' lobbyists knew that they were facing a long shot, since they were representing causes that held positions inconsistent with the Senator's consumer-oriented positions. But either they wanted at least a chance to make their case, or they were brought in by for-hire lobbyists who wanted to demonstrate to their clients that they could at least get a meeting. (Of course, this was hardly a significant accomplishment, since, as mentioned, the office had an open-door policy for all groups.)

While the majority of meeting requests involved persuasion attempts that were in line with a view of lobbying as primarily about information transmission, there was typically much less follow-up from meeting neutrals or groups opposed to the Senator's position than from allies. Many groups came in, made their case, and then left. Sometimes they would send follow-up e-mails if a relevant piece of legislation was coming to the floor. Only a very few groups were persistent. Ongoing discussions were more typical with allies.

The quality of lobbying varied tremendously. Some lobbyists were incredibly professional and sophisticated; others seemed to barely know where they were going. The best lobbyists followed up frequently and were aware of the information that the office needed. They provided glossy folders full of one-pagers and could be expected to offer proposed wording of amendments. However, I was surprised by how often I met lobbyists who were unable to answer basic questions, did not follow up, and were thoroughly ineffective. On three occasions, lobbyists were at least 15 minutes late for a scheduled meeting without letting me know ahead of time. The less professional lobbyists tended to represent small companies. Such experiences provide some support for Kersh's (2002) argument that lobbyists enjoy substantial autonomy because of their status as experts in Washington. The wide variation among lobbyists serves as yet another reminder to scholars that all lobbying is not the same.

\section{WHAT MAKES A WINNING LOBBY- IST?}

I would argue that when lobbyists are successful, it is because they are able to do it all. During my time in the Senate, every interest group that was successful achieved its goals because it found a legislator who was open to its position-a champion who was willing to talk to other senators, insist on a vote during a contentious floor battle, and make a compelling case in floor speeches and materials being circulated to different Senate offices. But successful lobbyists did not rely on their champions alone-they made the rounds of all Senate offices, explaining the merits of their issue, providing information and expertise on often-complicated technical issues, and frequently making dire threats about what "getting this wrong" would do to the economy. They operated in both the trenches of the details and the big intellectual framing of the issues. When the stars lined up well-when a group had a convincing argument, a good set of champions (ideally, bipartisan champions), a strong list of endorsements, a broad coalition, and limited opposition, victory was more likely. But most worked diligently despite less than desirable conditions and still wound up not getting what they wanted.

Ultimately, lobbying is far more of an art than a science. There is no simple recipe in which adding more of one thing monotonically increases the likelihood of an outcome. Even within a single piece of legislation, each issue posed its own unique dynamics, and different interests used different strategies. Some lobbyists had resources and smarts; others did not. There were no guarantees of victory. Presumably, as Heinz et al. suggested, "doing more of anything produces greater success than doing less, regardless of strategy" (1993, 348). However, Baumgartner et al.'s (2009) finding that more money does not reliably translate into more success given the many contingencies in lobbying also makes sense, and, as Heinz et al. conclude, "there is a considerable degree of uncertainty both in the nature of the decision process and the outcome of issue events" $(1993,358)$. My own experiences confirm this conclusion. Lobbying success seems not so much about engaging in more of any one strategy, but about being able to do many things and adjust quickly to changing circumstances.

Hopefully, this brief research note will encourage scholars to spend less time trying to model influence as a one-dimensional, transactional process and more time appreciating and investigating the contingencies and situations that make lobbying effective or ineffective, realizing that lobbyists do many different things, usually in tandem.

\section{R E F E R E N C E S}

Ansolabehere, Stephen, John M. de Figueiredo, and James M. Snyder Jr. 2003. "Why Is There So Little Money in U.S. Politics?" Journal of Economic Perspectives 17 (1): 105-30.

Austen-Smith, David, and John R. Wright. 1994. "Counteractive Lobbying." American Journal of Political Science 38 (1): 25-44.

Bauer, Raymond Augustine, Ithiel de Sola Pool, and Lewis Anthony Dexter. 1972. American Business and Public Policy: The Politics of Foreign Trade. 2nd ed. Chicago: Aldine.

Baumgartner, Frank R. 2009. Lobbying and Policy Change: Who Wins, Who Loses, and Why. Chicago: University of Chicago Press.

Esterling, Kevin M. 2004. The Political Economy of Expertise: Information and Efficiency in American National Politics. Ann Arbor: University of Michigan Press.

Hall, Richard L., and Alan V. Deardorff. 2006. "Lobbying as Legislative Subsidy.” American Political Science Review 100 (1): 69-84.

Hansen, John Mark. 1991. Gaining Access: Congress and the Farm Lobby, 1919-1981. American Politics and 
Political Economy Series. Chicago: University of Chicago Press.

Heinz, John P., Edward O. Laumann, Robert L. Nelson, and Robert H. Salisbury. 1993. The Hollow Core: Private Interests in National Policy Making. Cambridge: Harvard University Press.

Hojnacki, Marie, and David C. Kimball. 1998. "Organized Interests and the Decision of Whom to Lobby in Congress." American Political Science Review 92 (4): 775-90.

Kersh, Rogan. 2002. "Washington Lobbyists as Politi- cal Actors." In Interest Group Politics, ed. Allen Cigler and Burdett Loomis. 6th ed. Washington, DC: CQ Press.

Kollman, Ken. 1997. "Inviting Friends to Lobby: Interest Groups, Ideological Bias, and Congressional Committees." American Journal of Political Science 41 (2): 519-44.

Milbrath, Lester W. 1963. The Washington Lobbyists. Chicago: Rand McNally.

Schlozman, Kay Lehman, and John T. Tierney. 1986. Organized Interests and American Democracy. New
York: Harper \& Row.

Wright, John R. 1996. Interest Groups and Congress : Lobbying, Contributions, and Influence. New Topics in Politics Series. Boston: Allyn and Bacon.

Lee Drutman is a Ph.D. candidate in political science at the University of California, Berkeley. His dissertation examines the rise of business lobbying in Washington, $D C$

\section{Graduate Students Who Attended the Annual Meeting with APSA Assistance}

$\mathrm{T}$ $\mathrm{n}$ an effort to increase graduate student participation at the Annual Meeting, the association awarded Advanced Graduate Student Travel Grants for the 2010 meeting in Washington, DC. Recognizing challenging economic times across academia, Cambridge University Press offered \$5,000 and Pearson offered \$2,000 to supplement the APSA travel grant program and support U.S. graduate students taking part in the Annual Meeting. The names and institutional affiliates of the awardees follow.

\section{U.S. GRADUATE STUDENTS SUP- PORTED BY CAMBRIDGE UNIVER- SITY PRESS}

Mary Beth Altier, Princeton University Andrew Barwig, University of Denver Shaun Bevan, University of Manchester Constantine Boussalis, Claremont Graduate University

Stephanie Burchard, Rice University Sara Bush, Princeton University Patricia Cavanaugh, Carleton College Ryan Combs, University of Manchester Aaron Hale, University of Florida Matthew Leep, University of Connecticut Ashley Leinweber, University of Florida You-Te Liao, Institute of International Relations

Danielle Lussier, University of California, Berkeley

Christopher McKoy, University of California, Santa Barbara

Amy Nelson, University of California, Berkeley

Sara Newland, University of California, Berkeley

Benjamin Pasquale, New York University

Caryn Peiffer, Claremont Graduate University

Lesley Pruitt, University of Queensland

Brittany Stalsburg, Rutgers University,
New Brunswick

Jonathan Stillo, CUNY-Graduate Center

Laurence Tai, Harvard University

Kevin Walker, Claremont Graduate University

Dana Wittmer, Ohio State University

U.S. GRADUATE STUDENTS SUPPORTED BY PEARSON

Morris Bidjerano, SUNY, Albany

Ashley Conner, Stanford University

Karam Dana, Harvard University

Matthew DiGiuseppe, Binghamton University

Benjamin Graham, University of California, San Diego

William Norris, Massachusetts Institute of Technology

Stephen On, University of California, Los Angeles

Rachelle Suissa, Brooklyn College

\section{U.S. GRADUATE STUDENTS}

Michael Albertus, Stanford University

Gwendoline Alphonso, Cornell University

Ryan Baird, University of Arizona

Amanda Balzer, University of Nebraska, Lincoln

Kiran Banerjee, University of Toronto

Tiffany Barnes, Rice University

Barbra Barnett, Elmhurst College

Kelly Bay, Brown University

Curtis Bell, University of Colorado, Boulder

Philipp Bleek, Georgetown University Janna Bray, University of Michigan Amy Bromsen, Wayne State University Lisa Bryant, University of New Mexico Graham Bullock, University of California, Berkeley

Naomi Choi, University of California, Berkeley

Nick Clark, Indiana University

Meredith Conroy, Occidental College
Adam Cureton, University of North Carolina, Chapel Hill

Allan Dafoe, University of California, Berkeley

Papia Debroy, University of Michigan, Ann Arbor

Christian Donath, University of California, San Diego

Tao Dumas, Louisiana State University

Caitlin Dwyer, University of Minnesota, Twin Cities

Leif-Eric Easley, Harvard University

Andrea Everett, Princeton University

Eleanor Gao, University of Michigan

Michael Georger, Appalachian State University

Kristi Govella, University of California, Berkeley

Erin Graham, Ohio State University

Guy Grossman, Columbia University

Mario Guerrero, University of California, Santa Barbara

Jacqueline Hazelton, Brandeis University

Sara Henary, University of Virginia

David Hendry, University of Illinois at Urbana-Champaign

Alexis Henshaw, University of Arizona

Veronica Herrera, University of California, Berkeley

Catherine Herrold, Duke University

Andrea Jones-Rooy, University of Michigan, Ann Arbor

Eva Kaye-Zwiebel, University of Michigan, Ann Arbor

Jennifer Keister, University of California, San Diego

Athena King, University of South Carolina Brandon Kliewer, University of Georgia

Katrina Kosec, Stanford University

Kyle Kretschman, University of Texas at Austin

Ann Kryzanek, University of Georgia Peter LeQuire, University of Chicago Cyanne Loyle, University of Maryland 